This PDF is a selection from an out-of-print volume from the National Bureau of Economic Research

Volume Title: The Rate and Direction of Inventive Activity: Economic and Social Factors

Volume Author/Editor: Universities-National Bureau Committee for Economic Research, Committee on Economic Growth of the Social Science Research Council

Volume Publisher: Princeton University Press

Volume ISBN: 0-87014-304-2

Volume URL: http://www.nber.org/books/univ62-1

Publication Date: 1962

Chapter Title: The Future of Industrial Research and Development

Chapter Author: Yale Brozen

Chapter URL: http://www.nber.org/chapters/c2121

Chapter pages in book: (p. 273 - 276) 


\title{
The Future of Industrial Research and Development
}

\author{
YALE BROZEN \\ UNIVERSITY OF CHICAGO
}

RESEARCH in the laboratories of United States industry has grown for the past twenty-five years at a rate in excess of 15 per cent a year in dollar terms and 12 per cent a year in real terms. Growth in some industries has been even more rapid, of course, while in others it has fallen far short of these rates. Growth over the next fifteen years is projected at an annual rate of from 7 to 8 per cent. The portion of gross national product devoted to research and development is expected to rise from 1.9 to 3 per cent over this period with an ultimate ceiling at 5 per cent in the next century.

\section{Profits and Research Performed}

As research has increased, the profit performance of many segments of industry has changed in ways which appear to be related to their investments in this activity. Research spending in manufacturing industries is now much more closely related to subsequent sales and profits (see Table 1) than it was in the 1930's, when it amounted to less than 0.5 per cent of sales, and in the 1940's, when it was less than 1 per cent of sales.

The high correlation of research and subsequent profits points to the existence of a disequilibrium which may be indicative of a continued rapid growth of research spending in industrial laboratories. The correlation has, however, tended to deteriorate since 1957. This is one of the reasons for expecting a less rapid $R$ and $D$ growth in the future.

High research-high return industries are underinvesting in research and facilities. These industries will grow more rapidly than the low research-low return groups and, as a consequence, over-all spending on research will grow more rapidly than aggregate manufacturing sales even with a constant percentage of sales spent on research by each category.

Industries performing little research may be underinvesting in this activity. It seems apparent, however, that the low rate of spending in

Note: This paper is an abstract of an article entitled, "Trends in Industrial $\mathbf{R}$ and $\mathbf{D}$, ," which appeared in the Journal of Business, July 1960. 
TABLE 1

ReseARCH ExPENDITURES (1953 AND 1956) AND RATES OF RETURN (1957) BY INDUSTRIES

\begin{tabular}{|c|c|c|c|}
\hline \multirow[b]{2}{*}{ Industry } & \multicolumn{2}{|c|}{$\begin{array}{l}\text { Research Performed as a } \\
\text { Percentage of Sales }\end{array}$} & \multirow{2}{*}{$\begin{array}{c}\begin{array}{c}\text { Return on Net } \\
\text { Worth }\end{array} \\
1957\end{array}$} \\
\hline & 1953 & 1956 & \\
\hline Aircraft and parts & 8.9 & 17.6 & 17.8 \\
\hline Electrical equipment & 4.3 & 5.3 & 12.6 \\
\hline \multicolumn{4}{|l|}{ Professional, scientific and controlling } \\
\hline instruments & 4.1 & 4.8 & 12.0 \\
\hline Chemical and allied products & 2.1 & 2.3 & 13.2 \\
\hline Motor vehicles and other transp. & 1.3 & 2.3 & 12.5 \\
\hline Machinery (except electrical) & 1.3 & 2.1 & 10.7 \\
\hline ALL MANUFACTURING & 1.3 & 1.7 & 10.9 \\
\hline Rubber $^{a}$ & .99 & 1.3 & 11.2 \\
\hline Petroleum products ${ }^{a}$ & .57 & 0.80 & 12.4 \\
\hline Stone, clay, and glass & .55 & 0.70 & 12.3 \\
\hline Fabricated metal products & .40 & 0.57 & 9.3 \\
\hline Paper and allied products & .33 & 0.39 & 8.9 \\
\hline Primary metal $^{a}$ & .26 & 0.34 & 10.6 \\
\hline Food and kindred products & .11 & 0.15 & 8.6 \\
\hline Textile mill and apparel & .10 & 0.12 & 4.8 \\
\hline
\end{tabular}

SOURCE: Reviews of Data on Research and Development, May 1958 and August 1959, and National Science Foundation, Science and Engineering in American Industry, Final Report on a 1953-1954 Survey (NSF 56-16, Washington, 1956), provided data on total research performed. Total sales in each industry were obtained from The Economic Almanac 1958 (New York, Thomas Y. Crowell Company). Rates of return were taken from Quarterly Financial Report for Manufacturing Corporations, June 1958 (Federal Trade Commission-Securities and Exchange Commission).

${ }^{a}$ It should be noted that the rubber and petroleum industries may have an especially large understatement of book value (and overstatement of rate of return) relative to other industries because of the acquisition of government owned synthetic rubber facilities at favorable prices in 1955. The same is true of the primary metal industry because of its earlier acquisition of government owned aluminum and steel facilities.

the apparel, tobacco, food and beverage, textile, and iron and steel industries is primarily a consequence of the poorer scientific base available compared with that underlying the chemical, electrical, and instrument technologies.

\section{Research Spending by Industry Categories}

The great variation in research and development performance among industries is related to other factors besides the quality of the science base. New products, materials, or techniques appearing in an industry will lead to the spending of large amounts on research relative to sales. This relationship occurs partly because sales are low until a 
product is established and partly because much needs to be learned to perfect new products, to develop new applications and broaden markets, and to improve production processes. As these problems are solved and sales grow, the percentage of sales spent on research tends to drop unless more new products, materials, and processes appear (perhaps because of research in other industries) or improvements in the science base occur.

The scale of basic research performed in some industries (chemical, electrical, and petroleum) makes it likely that additions to the science base will occur at a rate which will prevent any decline in $R$ and $D$ performed relative to sales despite rapid growth of sales. Primary metal $R$ and $D$ seems likely to grow since a substantial proportion of the metal $\mathrm{R}$ and $\mathrm{D}$ budget is going to fundamental work. Also, products of basic research in universities and other nonprofit institutions and in government laboratories may appear in unexpected places and cause stagnating $R$ and $D$ programs to come to life.

\section{Government Influences in Industrial $R$ and $D$}

Government support of work in industrial laboratories appears to be an important factor in causing the present high level of performance. Yet, some evidence to the contrary exists. So long as the government supported research in the synthetic rubber industry, research remained at low levels. Since the sale of government owned facilities and the ending of research subsidies, privately performed $R$ and $D$ has grown sufficiently to raise over-all performance by 50 per cent. George Stigler and David Blank present evidence which may indicate that government spending simply replaces private spending, often causing private outlays to fall by more than the amount of public funds spent. ${ }^{1}$

\section{Other Factors Influencing $R$ and $D$ Outlays}

Growth in per capita income spurs research partly because the income elasticity of demand for the products of high research rate industries is large. Also, a larger market provides more room for diversity in products. An item whose niche in a small market would provide insufficient sales to justify development expense becomes worthwhile in a large market.

${ }^{1}$ The Demand and Supply of Scientific Personnel, Princeton University Press for National Bureau of Economic Research, 1957, p. 59. 
Low return industries are increasing their research and development spending, where possible, to improve their rate of return. Since the yield on additional capital is low in these industries, they turn their investment in the direction of moderate yield research projects which could not compete if high yielding equipment investment opportunities were available.

The restraining forces on $\mathrm{R}$ and $\mathrm{D}$ growth appear to be (1) the lack of growth in the rate of capital formation (which means little growth in an important market for the product of R and D), (2) the necessity of dipping deeper into the supply of talent as the amount absorbed increases, and (3) the absorption of a growing portion of gross saving by $R$ and $D$ which leaves less for further transfer from fixed asset investment in the future. 